\title{
Are Published Health Economic Models for Chronic Hepatitis B Appropriately Capturing the Benefits of HBsAg Loss? A Systematic Literature Review
}

\author{
Peter Wigfield $^{1}\left(\mathbb{D} \cdot\right.$ Urbano Sbarigia $^{2} \cdot$ Mahmoud Hashim $^{1} \cdot$ Talitha Vincken $^{1} \cdot$ Bart Heeg $^{1}$
}

Published online: 19 August 2019

(c) The Author(s) 2019

\begin{abstract}
Objectives Sustained hepatitis B surface antigen (HBsAg) loss or 'functional cure' (FC) is considered an optimal treatment endpoint by international clinical guidelines for chronic hepatitis B (CHB), yet rarely is this achieved with current standard of care (SoC). This leads to an under-reporting of FC in clinical trials, observational studies and health economic (HE) models. This paper systematically identifies and assesses how FC is incorporated in published HE models of CHB.

Methods A systematic literature review was conducted in PubMed and Embase (conducted February 2019) to review how HBsAg loss is captured in HE models. The following items were extracted: rate of (and transition probabilities to) $\mathrm{HBsAg}$ loss, HBsAg loss health state costs, and HBsAg loss health state utilities.

Results Sixty-five economics evaluations were identified, and $<50 \%$ of these (27/65) incorporated HBsAg loss in their models. Only 15/27 stated HBsAg loss health state costs, 15/27 stated HBsAg loss health state utilities, and 11/27 mentioned treatment-specific transition probabilities to HBsAg loss. The majority of sources these inputs were derived from are not transparent.

Conclusions The benefits of FC in current HE models are not well captured, as FC is often not reported or not directly related to modelled treatments. This has the potential for novel agents with higher efficacy compared with SoC to be overlooked and undervalued if their worth is not appropriately communicated. In order to ensure optimal access for patients to new and effective therapies, it is important that the benefits of FC are better assessed and captured within HE models.
\end{abstract}

Peter Wigfield and Urbano Sbarigia contributed equally to the work.

Electronic supplementary material The online version of this article (https://doi.org/10.1007/s41669-019-00175-w) contains supplementary material, which is available to authorized users.

Peter Wigfield

peter.wigfield@ingress-health.com

Urbano Sbarigia

usbarigi@its.jnj.com

Mahmoud Hashim

mahmoud.hashim@ingress-health.com

Talitha Vincken

talitha.vincken@ingress-health.com

Bart Heeg

bart.heeg@ingress-health.com

1 Ingress-health Nederland, Hofplein 20, 3032 AC Rotterdam, The Netherlands

2 Janssen Pharmaceutica, Turnhoutseweg 30, 2340 Beerse, Belgium

\section{Key Points for Decision Makers}

The benefits of functional cure in current health economic models are not well captured, as functional cure is often not reported or not directly related to modelled treatments.

In order to ensure optimal access for patients to new and effective therapies, it is important that the benefits of functional cure are better assessed and captured within health economic models.

\section{Background}

Although a prophylactic vaccine for hepatitis B virus (HBV) has been available since 1982, HBV still severely threatens the lives of an estimated 257 million people worldwide [1,2]. In 2015, complications related to the 
disease (including cirrhosis and liver cancer) were responsible for approximately 887,000 deaths globally [1]. The reasons for this may be due to various factors, including availability and reimbursement issues (especially in middle-income countries that experience high prevalence levels), suboptimal coverage due to a lack of treatment and screening services, and a lack of education and awareness promotions to prevent viral transmission.

Current standard of care (SoC) for chronic hepatitis B (CHB) aims to keep viral replication under control and reduce the risk of liver damage and any other further complications in order to improve long-term survival. There are currently two main treatment options for CHB: treatment with a nucleoside analogue (e.g., adefovir [ADV], entecavir [ETV], lamivudine [LAM], telbivudine [LdT], tenofovir disoproxil fumarate [TDF], and tenofovir alafenamide [TAF]), or treatment with pegylated interferon- $\alpha-2$ (PEG IFN) [3].

The World Health Organization (WHO) recommends the use of oral antiviral agents, with a particular preference for TDF/TAF or ETV since these are regarded as the most potent, rarely lead to drug resistance (relative to antivirals that have lower barriers to resistance, such as LAM, LdT or ADV) and have relatively few side effects [4]. Nucleosides are usually administered for long periods of time in order to keep the virus under control. Despite the efficacy in reducing viral load, in most cases treatment does not cure $\mathrm{HBV}$ and is the reason why patients are maintained on these agents.

PEG IFN is an option for those patients with a well functioning liver [5] (its use in decompensated cirrhosis is often avoided due to life-threatening flare-ups and infections [6]). It is usually administered by injection for finite periods of time (usually 48 weeks [7]) and can be an effective alternative; however, its severe side effects often make it an unfavourable choice amongst many patients. Either discontinuation of therapy or suboptimal exposure to treatments can also result in a rebound of the viral load, which can lead to disease progression and an increased risk of viral transmission [1].

According to the American Association for the Study of Liver Diseases (AASLD 2018 [7]), Asian Pacific Association for the Study of the Liver (APASL 2016 [8]), European Association for the Study of the Liver (EASL 2017 [9]), and National Institute for Health and Care Excellence (NICE 2013 [updated 2017] [10]) guidelines on the management of HBV, hepatitis B surface antigen (HBsAg) loss is a key endpoint of interest that is strongly recommended [2]. Other recommended endpoints include long-term suppression of HBV deoxyribonucleic acid (DNA) levels, hepatitis B envelope antigen $(\mathrm{HBe} A g)$ loss with/without seroconversion of the antibodies produced against $\mathrm{HBeAg}$ (i.e., anti-HBe seroconversion), and alanine aminotransferase (ALT) normalisation.

Sustained HBsAg loss (or seroconversion [HBsAg SC]) is regarded as an optimal endpoint for patients with CHB. It indicates profound viral suppression and is associated with a sustained reduction in viral and other disease markers in the blood even after treatment has been withdrawn [3, 11]. HBsAg loss is commonly termed 'functional cure' (FC), but rarely is this ever achieved using currently available antivirals [2]. This may lead to an under-reporting of FC in clinical trials, observational studies and health economic (HE) models. Most published randomised controlled trials (RCTs) record annual HBsAg loss rates that rarely reach $>4 \%$ for nucleoside therapies [12-17], and usually around 4-10\% for PEG IFN [18-21] (though 20\% [22] and 21\% [23] have been seen in some cases, with low sample sizes appearing to have an influence, i.e., two and three patients experiencing HBsAg loss, respectively).

Economic evaluation (EE) is an important part of health economics that provides a framework to make best use of clinical evidence through an organised consideration of the effects of all available alternatives on health, healthcare costs and other outcomes that are regarded as valuable [24]. Taking this into account, although sustained off-therapy HBsAg loss is a favourable endpoint for $\mathrm{CHB}$ patients, it is unclear the extent to which this health state is taken into consideration in current HE models of the disease.

Low reported loss rates in SoC therapies may mean FC as an outcome of interest is often overlooked in current $\mathrm{HE}$ models of CHB. This has the potential to undervalue novel treatments that succeed in achieving higher levels of $\mathrm{HBsAg}$ loss and, consequently, may hinder their availability to patients in the future.

Therefore, our objective is to systematically identify and assess how FC is incorporated in currently published HE models of CHB. This will involve investigating the extent to which the following components are included:

- HBsAg loss health state costs

- HBsAg loss health state utilities

- Treatment-specific HBsAg loss rates/transition probabilities

\section{Methods}

A systematic literature review was conducted in accordance with the Preferred Reporting Items for Systematic Reviews and Meta-Analyses (PRISMA) Statement to review how HBsAg loss is captured in HE models (see Supplemental Fig. 1 in the Electronic Supplementary Material [ESM]) [25]. In February 2019, two bibliographic databases (PubMed and Embase) were searched to identify published cost-effectiveness studies in CHB, 
restricted to English language publications and with no limitation on publication date (search syntaxes are available in Supplemental Table 1 and Supplemental Table 2, see ESM). Though EE databases could also have been included, the results obtained from PubMed and Embase were determined to be extensive enough for a pragmatic review to be undertaken.

Two investigators (PW, MH) independently reviewed the titles, abstracts and full texts of retrieved articles sequentially using the predefined eligibility criteria. At the full-text stage, references in publications were also reviewed to identify any further relevant studies. Upon agreement of the final list of included articles, data were extracted into a predefined Microsoft Excel template and were subsequently independently validated. Any inconsistencies between either the retrieved articles or subsequent data extracted by the two investigators were individually discussed with an experienced third party member (US) until the disparity was resolved.

The following data items were extracted: study identification items (e.g., PubMed ID, first author, study year, etc.), study characteristics (type of economic analysis, model structure, study population, health states, time horizon, country perspective, funding sources), disease characteristics (baseline $\mathrm{HBeAg}$ status, baseline cirrhosis status), interventions compared, and $\mathrm{HBsAg}$ health state inputs (both natural history and treatment-specific inputs).

\subsection{Inclusion/Exclusion Criteria}

Only cost-effectiveness studies comparing two or more interventions to treat $\mathrm{CHB}$ that were written in English were included for data extraction (budget impact analyses, economic burden of disease studies, cost of illness studies, cost analyses, cost impact analyses, dose-response studies, duration-response studies, literature reviews or network meta-analyses were excluded). All inclusion and exclusion criteria adhered to during the systematic literature review are outlined in Supplemental Table 3 (see ESM).

EEs considered for full-text screening included all those with study populations that had a diagnosis of CHB infection and were $\geq 2$ years of age. EEs that included special patient populations, that is, pregnant women at baseline, patients with any type of cancer or receiving treatment for cancer at the beginning of the study, or coinfected patients, were excluded. A total of 1926/2182 studies were excluded after screening as outlined in Supplemental Fig. 1 (ESM). The reason for excluding special patient populations was so that a sizeable number of models could be reviewed. EEs comparing either nucleosides and/or interferons used to treat patients with $\mathrm{CHB}$ were included, whilst interventions involving either screening/prevention strategies or HBV prophylaxis were not. This was because interventions in other settings are either finite or have different therapeutic goals (i.e., not related to HBsAg loss, which was the aim of this review). We assumed that the current indication is the main indication in CHB for which key economic models of the disease are developed by industry.

EEs were screened for the HBsAg health state. For studies that contained this state, the following items were extracted: rate of HBsAg loss or seroconversion, transition probabilities to HBsAg loss, HBsAg health state costs and HBsAg health state utilities. Studies reporting health-related quality of life (HRQoL) or health state utility measures as their sole outcome were excluded.

\section{Results}

\subsection{Overview of Included Studies}

Of the 2182 papers screened, 65 were identified as EEs that met the inclusion criteria and were used as part of the subsequent review (see Supplemental Table 4 [ESM] for an overview of all included studies).

In terms of type of economic analyses, the vast majority were cost utility analyses (50/65), with cost-effectiveness analyses making up only 12 of the total included studies [26, 31, 52-61]. One study employed a perceived value assessment (PVA) method that is described by the authors as a novel health economics methodology developed by Monitor Deloitte (formerly Monitor Group) [27, 62].

Markov modelling was the most commonly seen modelling approach (53/65), followed by decision-tree modelling, which was utilised in 12 of the 65 studies $[53,55,60,61$, 63-70] (note that two studies used a combination of Markov modelling and decision-tree modelling in their EEs in order to separate their analysis according to either a short-term or long-term time horizon [55, 63]).

Regarding country perspective, nearly 20 different countries conducted these published HE models. China undertook the largest share (reported in 13 of the 65 studies [27, $31,32,34,56,69,71-77])$, closely followed by the US $(10 / 65[46-48,51,52,64,70,78-80])$ and the UK (7/65 $[33,43-45,49,54,81])$.

Of the 65 EEs included, $<50 \%$ of these $(27 / 65)$ incorporated HBsAg loss/seroclearance in their models (see Table 1). Furthermore, only $15 / 27$ stated HBsAg loss health state costs (see Table 2), only 15/27 stated HBsAg loss health state utilities (see Table 4) and only 11 of these 27 studies explicitly mentioned treatment-specific transition probabilities to the HBsAg loss health state from other health states (see Supplementary Table 5 [ESM]). 
Table 1 Studies that incorporated HBsAg loss/seroclearance in their models (27/65)

\begin{tabular}{|c|c|c|c|c|}
\hline Study & Title & Country & Economic analysis type & Model structure \\
\hline Kockaya et al. 2015 [26] & $\begin{array}{l}\text { Cost-effectiveness analysis of oral anti-viral drugs } \\
\text { used for treatment of chronic hepatitis B in Turkey }\end{array}$ & TUR & CEA & Markov \\
\hline Wei et al. 2013 [27] & $\begin{array}{l}\text { A novel estimation of the impact of treatment with } \\
\text { entecavir on long-term mortality, morbidity and } \\
\text { healthcare costs of chronic hepatitis B in China }\end{array}$ & $\mathrm{CHN}$ & PVA method & Markov \\
\hline Ruggeri et al. 2017 [28] & $\begin{array}{l}\text { Economic analysis and budget impact of tenofovir } \\
\text { and entecavir in the first-line treatment of hepatitis } \\
\text { B virus in Italy }\end{array}$ & ITA & CUA & Markov \\
\hline Chinnaratha et al. 2017 [29] & $\begin{array}{l}\text { Assessing the clinical and economic impact of } \\
\text { increasing treatment uptake in chronic hepatitis B } \\
\text { infection using a Markov model }\end{array}$ & AUS & CUA & Markov \\
\hline Keshavarz et al. 2016 [30] & $\begin{array}{l}\text { A cost-utility and cost-effectiveness analysis of dif- } \\
\text { ferent oral antiviral medications in patients with } \\
\text { HBeAg-negative chronic hepatitis B in Iran: an } \\
\text { economic microsimulation decision model }\end{array}$ & IRN & CUA & Markov \\
\hline Banerjee et al. 2016 [31] & $\begin{array}{l}\text { Telbivudine for the treatment of chronic hepatitis } \\
\text { B in HBeAg-positive patients in China: a health } \\
\text { economic analysis }\end{array}$ & $\mathrm{CHN}$ & CEA & Markov \\
\hline Toy et al. 2015 [32] & $\begin{array}{l}\text { Cost-effectiveness and cost thresholds of generic and } \\
\text { brand drugs in a national chronic hepatitis B treat- } \\
\text { ment program in China }\end{array}$ & $\mathrm{CHN}$ & CUA & Markov \\
\hline Bermingham et al. 2015 [33] & $\begin{array}{l}\text { Cost-effectiveness analysis of alternative antiviral } \\
\text { strategies for the treatment of HBeAg-positive and } \\
\text { HBeAg-negative chronic hepatitis B in the United } \\
\text { Kingdom }\end{array}$ & UK & CUA & Markov \\
\hline Zhang et al. 2015 [34] & $\begin{array}{l}\text { Cost-effectiveness analysis of antiviral therapies for } \\
\text { hepatitis B e antigen-positive chronic hepatitis B } \\
\text { patients in China }\end{array}$ & $\mathrm{CHN}$ & CUA & Markov \\
\hline Lo et al. 2015 [35] & $\begin{array}{l}\text { Cost effectiveness of response-guided therapy with } \\
\text { peginterferon in the treatment of chronic hepatitis B }\end{array}$ & HKG & CUA & Markov \\
\hline Iannazzo et al. 2013 [36] & $\begin{array}{l}\text { Individualized treatment of } \mathrm{HBe} A g-n e g a t i v e ~ c h r o n i c \\
\text { hepatitis B using pegylated interferon-ÎI } \pm 2 \mathrm{a} \text { as first- } \\
\text { line and week-12 HBV DNA/HBsAg stopping rule: } \\
\text { a cost-effectiveness analysis }\end{array}$ & ITA & CUA & Markov \\
\hline Hulstaert et al. 2013 [37] & $\begin{array}{l}\text { Should chronic hepatitis B be treated as early as pos- } \\
\text { sible? }\end{array}$ & BEL & CUA & Markov \\
\hline He et al. 2012 [38] & $\begin{array}{l}\text { Cost-effectiveness analysis of antiviral treatments for } \\
\text { HBeAg-positive chronic hepatitis B in Canada }\end{array}$ & CAN & CUA & Markov \\
\hline Toy et al. 2012 [39] & $\begin{array}{l}\text { The cost-effectiveness of treating chronic hepatitis B } \\
\text { patients in a median endemic and middle income } \\
\text { country }\end{array}$ & TUR & CUA & Markov \\
\hline Dakin et al. 2011 [40] & $\begin{array}{l}\text { Cost effectiveness of tenofovir disoproxil fumarate for } \\
\text { the treatment of chronic hepatitis B from a Canadian } \\
\text { public payer perspective }\end{array}$ & CAN & CUA & Markov \\
\hline Colombo et al. 2011 [41] & $\begin{array}{l}\text { A cost-effectiveness analysis of different therapies in } \\
\text { patients with chronic hepatitis B in Italy }\end{array}$ & ITA & CUA & Markov \\
\hline Wiens et al. 2011 [42] & $\begin{array}{l}\text { Cost-effectiveness of telbivudine versus lamivudine } \\
\text { for chronic hepatitis B }\end{array}$ & BRA & CUA & Markov \\
\hline Dakin et al. 2010 [43] & $\begin{array}{l}\text { Cost-utility analysis of tenofovir disoproxil fumarate } \\
\text { in the treatment of chronic hepatitis B }\end{array}$ & UK & CUA & Markov \\
\hline Shepherd et al. 2009 [44] & $\begin{array}{l}\text { Entecavir for the treatment of chronic hepatitis B } \\
\text { infection }\end{array}$ & UK & CUA & Markov \\
\hline Jones et al. 2009 [45] & $\begin{array}{l}\text { Adefovir dipivoxil and pegylated interferon alpha } \\
\text { for the treatment of chronic hepatitis B: an updated } \\
\text { systematic review and economic evaluation }\end{array}$ & UK & CUA & Markov \\
\hline Spackman and Veenstra 2008 [46] & $\begin{array}{l}\text { A cost-effectiveness analysis of currently approved } \\
\text { treatments for HBeAg-positive chronic hepatitis B }\end{array}$ & US & CUA & Markov \\
\hline
\end{tabular}


Table 1 (continued)

\begin{tabular}{|c|c|c|c|c|}
\hline Study & Title & Country & Economic analysis type & Model structure \\
\hline Veenstra et al. 2008 [47] & $\begin{array}{l}\text { Evaluating anti-viral drug selection and treatment } \\
\text { duration in HBeAg-negative chronic hepatitis B: a } \\
\text { cost-effectiveness analysis }\end{array}$ & US & CUA & Markov \\
\hline Veenstra et al. 2007 [48] & $\begin{array}{l}\text { Cost effectiveness of entecavir versus lamivudine } \\
\text { with adefovir salvage in HBeAg-positive chronic } \\
\text { hepatitis B }\end{array}$ & US & CUA & Markov \\
\hline Takeda et al. 2007 [49] & $\begin{array}{l}\text { A systematic review and economic evaluation of } \\
\text { adefovir dipivoxil and pegylated interferon-alpha- } 2 \mathrm{a} \\
\text { for the treatment of chronic hepatitis B }\end{array}$ & UK & CUA & Markov \\
\hline Pwu and Chan 2002 [50] & $\begin{array}{l}\text { Cost-effectiveness analysis of interferon-alpha therapy } \\
\text { in the treatment of chronic hepatitis B in Taiwan }\end{array}$ & TAI & CUA & Markov \\
\hline Louis-Jacques and Olson 1997 [51] & $\begin{array}{l}\text { Cost-benefit analysis of interferon therapy in children } \\
\text { with chronic active hepatitis B }\end{array}$ & US & CBA & NA \\
\hline Wong et al. 1995 [52] & $\begin{array}{l}\text { Cost-effectiveness of interferon-alpha } 2 \mathrm{~b} \text { treatment for } \\
\text { hepatitis B e antigen-positive chronic hepatitis B }\end{array}$ & US & CEA & Markov \\
\hline
\end{tabular}

AUS Australia, BEL Belgium, BRA Brazil, CAN Canada, CBA cost-benefit analysis, $C E A$ cost-effectiveness analysis, $C H N$ China, $C U A$ cost-utility analysis, $H B e A g$ hepatitis B envelope antigen, $H B s A g$ hepatitis B surface antigen, $H K G$ Hong Kong, IRN Iran, ITA Italy, NA not applicable, PMID PubMed ID, PVA perceived value assessment, TAI Taiwan, TUR Turkey, UK United Kingdom, US United States

\subsection{HBsAg Loss Health State Costs}

Table 2 provides an overview of the 15 studies that explicitly mentioned HBsAg loss health state costs. Four studies were conducted using a US country perspective [46-48, 52], four were conducted using a UK perspective [45, 49, 87, 88], three were conducted using China as their country perspective [27, 31, 34], one was conducted using an Australian country perspective [29] and one used a Taiwan perspective [50]. Note that the studies by Wong et al. 1995 [52] and Pwu and Chan 2002 [50] are mentioned twice in the table since two relevant health state costs have been recorded (i.e., HBsAg loss in combination with compensated cirrhosis [CC], and HBsAg loss alone).

For all studies outlined in Table 2, the specific health state has been described along with the health state cost per year as recorded in the accompanying study. All studies describe cost per year of the health state.

The health state cost per year reported from the studies has then been converted to 2019 US dollars (US\$). This enables comparison of reported costs across studies and shows that the values cited in the articles range widely from US $\$ 0.00[29,45,49,87]$ to US $\$ 1377.45$ [31] per year when investigating HBsAg loss health state costs alone (this increases to US\$2472.77 if HBsAg loss in combination with $\mathrm{CC}$ is included, i.e. $\mathrm{CC}$ is a large cost driver in this instance). There is also a large disparity seen when the HBsAg loss health state is included: five studies [27, 31, 34, 50, 52] state costs between US\$814.83 [40] and US\$1377.45 [31], whilst 11 studies [29, 38, 43, 45-50, 52, 87] state costs between US\$0.00 [29, 45, 49, 87] and US\$224.62 [50].
In order to investigate these costs further, the sources these costs have been referenced from have been included in the table alongside a description of the study type. Some short notes detailing how these sources refer to HBsAg health state costs are also provided.

As is seen in Table 2, other than the studies that rely on expert opinion and assumptions to determine HBsAg loss health state costs, the vast majority of sources that were used to collect such costs for the original studies [27, 31, 34, 38, $40,43,46-48]$ do not specifically mention any relevant costs in their articles. The remaining two studies either referred to the Clinical Cost Manager accounting system at the New England Medical Center as their source [52], or Southampton University Hospitals Trust in combination with expert opinion [87]; neither of which were available for this review.

In order to elucidate this further, an overview of the health state cost references recorded in the articles were investigated and are outlined in Table 3 . As can be seen, the only source that specifically mentions a value for $\mathrm{HBsAg}$ loss (in this case seroconversion) is Dakin et al. 2010 [86], which states a yearly cost of US\$5.32. All other sources fail to mention an explicit cost for HBsAg loss, instead outlining yearly costs for other health states (including CHB, CC, decompensated cirrhosis, hepatocellular carcinoma and liver transplant). From looking at Table 3, it is likely that (when included in the studies) the health state costs for $\mathrm{HBsAg}$ loss have been predicted by the authors from other CHB health states. 


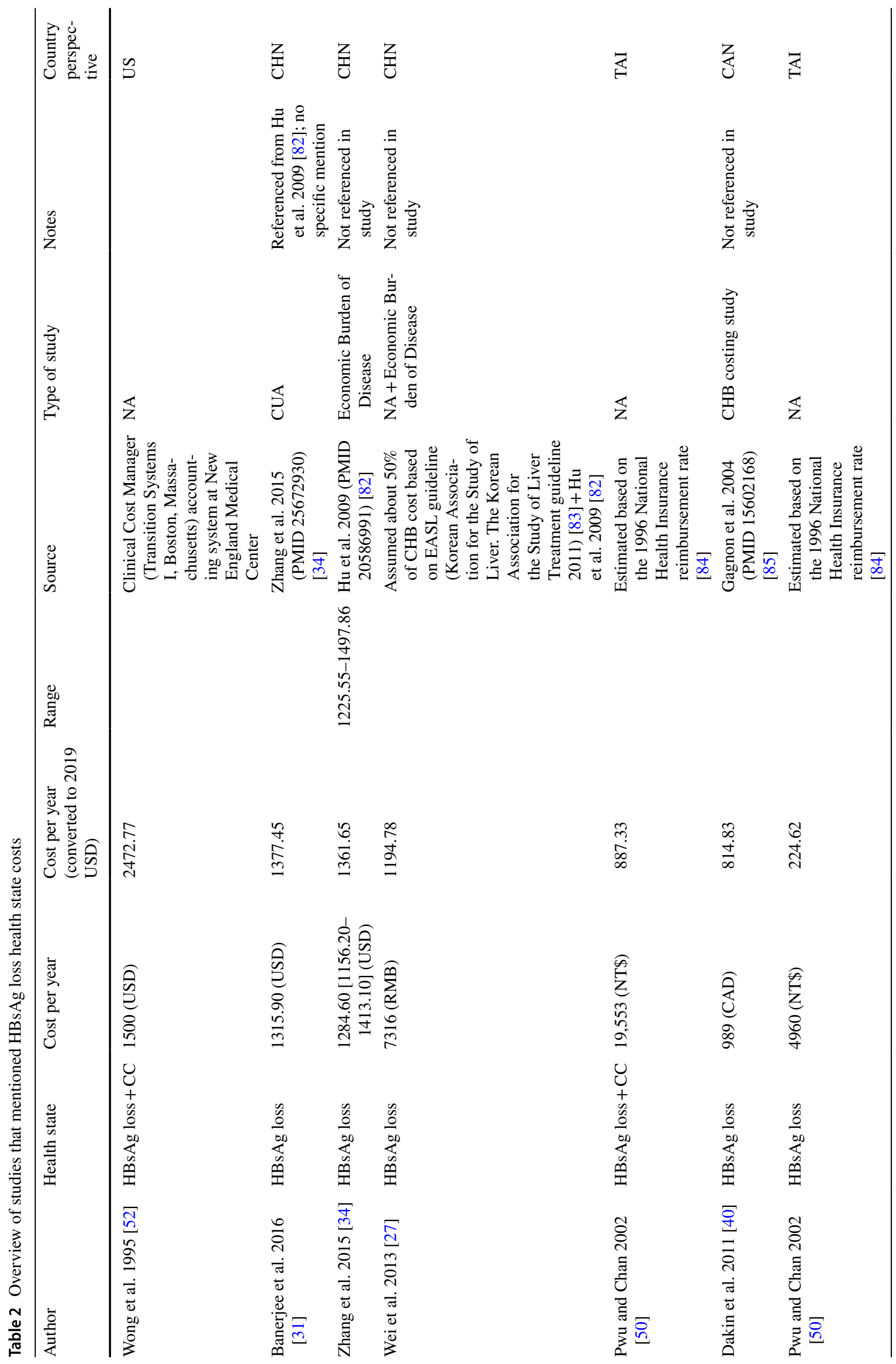




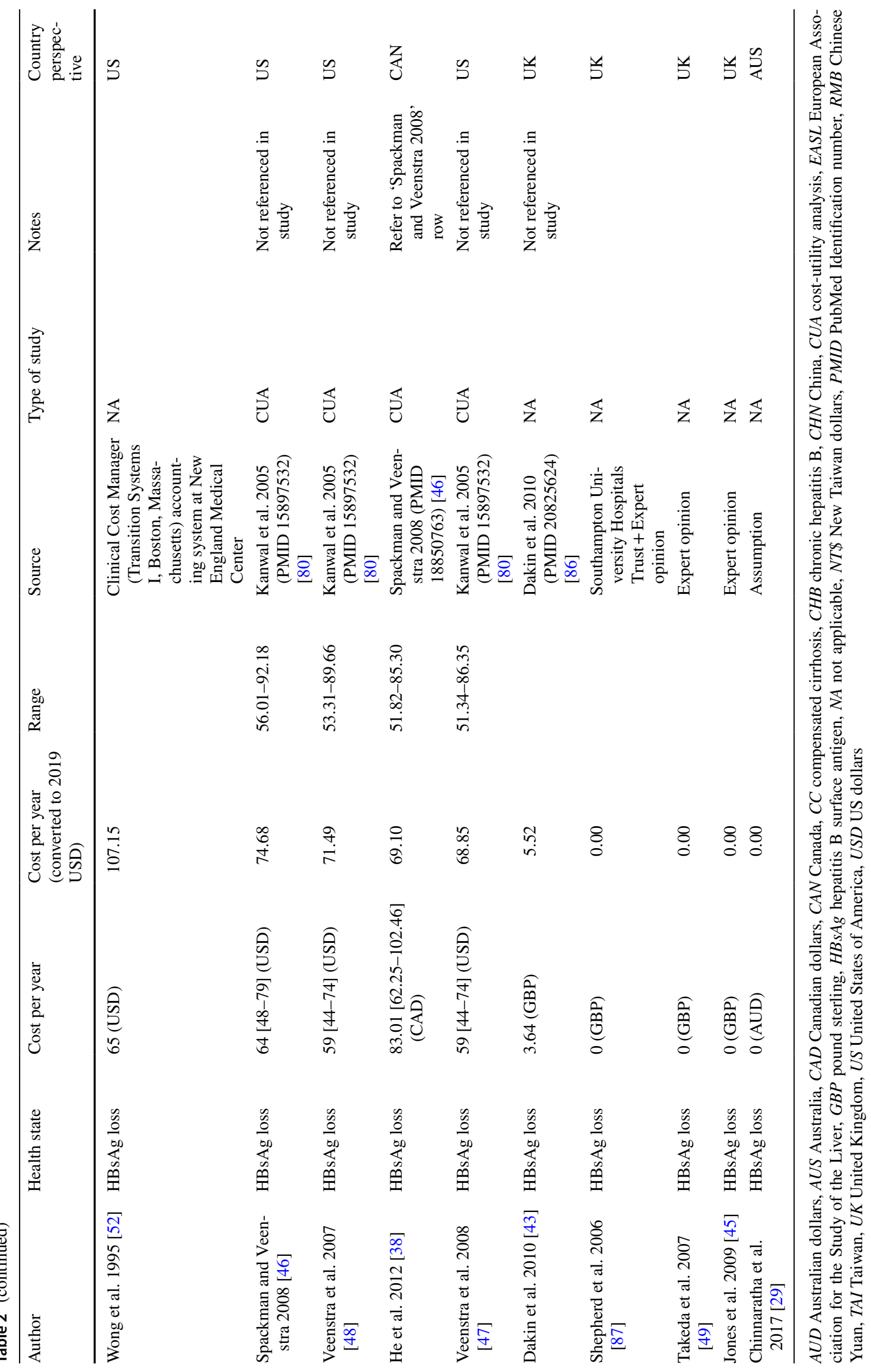


Table 3 CHB costs outlined from sources referenced (converted to 2019 USD)

\begin{tabular}{|c|c|c|c|c|c|c|c|c|c|}
\hline Author & $\begin{array}{l}\text { CHB (not } \\
\text { specified) }\end{array}$ & CHB (treated) & $\begin{array}{l}\text { CHB } \\
\text { (untreated) }\end{array}$ & $\mathrm{HBeAg} \mathrm{SC}$ & HBsAg SC & $\mathrm{CC}$ & $\mathrm{DC}$ & $\mathrm{HCC}$ & LT \\
\hline Hu and Chen 2009 [82] & 1953 & & & & & 3310 & 5505 & 7898 & \\
\hline Gagnon et al. 2004 [85] & 2634 & & & & & 3104 & 11,668 & 13,874 & 102,952 \\
\hline Kanwal et al. 2005 [80] & & & & & & 1264 & & 50,776 & 167,220 \\
\hline Dakin et al. 2010 [86] & & 552 & 496 & 354 & 5.32 & 1959 & 15,701 & 13,992 & 88,059 \\
\hline
\end{tabular}

$C A N$ Canada, $C C$ compensated cirrhosis, $C H B$ chronic hepatitis B, DC decompensated cirrhosis, $H B e A g S C$ hepatitis B envelope antigen seroconversion, HBsAg SC hepatitis B surface antigen seroconversion, $H C C$ hepatocellular carcinoma, LT liver transplant, USD US dollars

\subsection{HBsAg Loss Health State Utilities}

Table 4 presents an overview of the 15 studies that explicitly mentioned HBsAg loss health state utilities. Four were conducted using China as their country perspective [27,31, $32,34]$, three studies were conducted using a US country perspective [46-48], three were conducted using a UK perspective [33, 43, 45], two were conducted using a Canadian perspective $[38,40]$ and the remaining three studies used an Australian [29], Iranian [30] and Italian [36] country perspective, respectively.

For all studies outlined in Table 4, the health state utility value specific to the HBsAg loss health state is reported. As seen, the utility values used in the studies range fairly substantially from 0.71 (reported in three studies [27, 31, $34]$ ) to 0.99 (reported in four studies [32, 46-48]). As was undertaken for HBsAg health state costs, the sources these utilities were referenced from have been included in the table alongside a description of the study type. Some short notes detailing how these sources refer to HBsAg loss health state utilities are also included.

Other than the study by He et al. 2012 [38], which relied on assumptions to calculate the HBsAg health state utilities, a total of five sources [52, 89-92] were used for the remaining studies.

For three of the four studies that used a utility value of 0.99 (Veenstra et al. [47, 48] and Spackman and Veenstra 2008 [46]), it was assumed that the HBsAg loss health state utility was equal to the $\mathrm{HBeAg}$ seroconversion health state utility using Wong et al. [52] as a reference. For the remaining study that reported a value of 0.99 [32], Levy et al. [89] was referenced yet there was no mention of a utility value of HBsAg loss in the study. Levy et al. [89] was also referenced for six other studies [27, 29, 31, 32, 34, 36, 45].

For the majority of the studies, a utility value specific to HBsAg loss was not able to be identified from the sources referenced in the original articles. The remaining studies either used a utility value for non-cirrhotic CHB [33] or used "UK population norms for EQ-5D" [40, 86].

\subsection{Treatment-Specific HBsAg Loss Rates/Transition Probabilities}

Supplemental Table 5 (see ESM) provides an overview of the 11 studies that explicitly mentioned treatment-specific transition probabilities for the HBsAg loss health state. The transition probabilities used in the models are shown along with the $\mathrm{HBeAg}$ status of the population referred to (when $\mathrm{HBeAg}$ status has not been specified, this has been recorded as such in the table). Though efficacy values are presented for each treatment, it is important to note that comparisons between regimens must be conducted with caution. This is because of the heterogeneity of the baseline patient populations and study designs between trials, which will undoubtedly affect the outcomes explored.

For TDF, annual HBsAg loss rates between 0.7\% (Banerjee et al. [31]) and 10\% (Ruggeri et al. [28]) are used in $\mathrm{HBeAg}$-positive patients, with Colombo et al. [41] and Ruggeri et al. [28] presenting increasing annual rates beginning from $3 \%$ and 3.2\% respectively in year one. In $\mathrm{HBeAg}$ negative patients, a $0 \%$ annual loss rate is used in Colombo et al. [41] and a $12 \%$ lifetime loss rate is used by Lo et al. [35]. For studies that did not differentiate HBsAg loss rates by HBeAg status, Chinnaratha et al. [29] used an annual rate of $0.8 \%$, and Iannazzo et al. [36] used an annual rate of $0.4 \%$.

For LAM, annual HBsAg loss rates between $0 \%$ (Colombo et al. [41]) and 14\% (Jones et al. [45]) are used in HBeAg-positive patients, with Zhang et al. [34] and Banerjee et al. [31] both reporting annual rates of $0.7 \%$. Colombo et al. [41] is the only study that reported a loss rate for $\mathrm{HBeAg}$-negative patients (0\%), and $\mathrm{He}$ et al. [38] used a loss rate that was equal to baseline (this was for all patients regardless of $\mathrm{HBe} \mathrm{Ag}$ status).

For ADV, annual HBsAg loss rates ranged more conservatively between $0 \%$ (Colombo et al. [41]) and 1.3\% (Zhang et al. [34] and Banerjee et al. [31]) in HBeAg-positive patients. Again, Colombo et al. [41] is the only study that reported a loss rate for $\mathrm{HBeAg}$-negative patients $(0 \%)$, whilst no studies reported a loss rate that was not specific to a particular HBeAg status. 
Table 4 Overview of studies that mentioned HBsAg health state utilities

\begin{tabular}{|c|c|c|c|c|c|c|}
\hline Author & Utility value & Range & Source & Type of study & Notes & $\begin{array}{l}\text { Country } \\
\text { perspec- } \\
\text { tive }\end{array}$ \\
\hline Veenstra et al. 2008 [47] & 0.99 & $0.94-1.00$ & Wong et al. 1995 [52] & CEA & $\begin{array}{l}\text { Utility assumed same as } \mathrm{HBe} A g \\
\text { seroconversion }\end{array}$ & US \\
\hline Veenstra et al. 2007 [48] & 0.99 & $0.94-1.00$ & Wong et al. 1995 [52] & CEA & $\begin{array}{l}\text { Utility assumed same as } \mathrm{HBeAg} \\
\text { seroconversion }\end{array}$ & US \\
\hline $\begin{array}{l}\text { Spackman and Veenstra } 2008 \\
\text { [46] }\end{array}$ & 0.99 & $0.94-1.00$ & Wong et al. 1995 [52] & CEA & $\begin{array}{l}\text { Utility assumed same as } \mathrm{HBeAg} \\
\text { seroconversion }\end{array}$ & US \\
\hline Toy et al. 2015 [32] & 0.99 & $0.90-1.00$ & Levy et al. 2008 [89] & QoL study & $\begin{array}{l}\text { Infected and uninfected CHB } \\
\text { health state utilities (CHN, } \\
\text { HKG, CAN, US, GBR, ESP) - } \\
\text { no mention of HBsAg loss }\end{array}$ & $\mathrm{CHN}$ \\
\hline Keshavarz et al. 2016 [30] & 0.95 & & $\begin{array}{l}\text { EQ-5D question- } \\
\text { naire + Goudarzi } \\
2014[90]\end{array}$ & Interviews & Unpublished sources & IRN \\
\hline He et al. 2012 [38] & 0.9 & $0.85-0.95$ & Assumption & NA & & CAN \\
\hline Bermingham et al. 2015 [33] & 0.87 & $0.85-0.88$ & Woo et al. 2012 [91] & QoL study & Utility for non-cirrhotic $\mathrm{CHB}$ & UK \\
\hline Iannazzo et al. 2013 [36] & 0.87 & $0.7-1$ & Levy et al. 2008 [89] & QoL study & $\begin{array}{l}\text { Infected and uninfected CHB } \\
\text { health state utilities (CHN, } \\
\text { HKG, CAN, US, GBR, } \\
\text { ESP)—no mention of HBsAg } \\
\text { loss }\end{array}$ & ITA \\
\hline Dakin et al. 2011 [40] & 0.86 & SE 0.0039 & Kind et al. 1999 [92] & QoL study & $\begin{array}{l}\text { "UK population norms for } \\
\text { EQ-5D" }\end{array}$ & CAN \\
\hline Dakin et al. 2010 [86] & 0.86 & $0.85-0.87$ & Kind et al. 1999 [92] & QoL study & $\begin{array}{l}\text { "UK population norms for } \\
\text { EQ-5D" }\end{array}$ & UK \\
\hline Chinnaratha et al. 2017 [29] & 0.79 & $0.77-0.80$ & Levy et al. 2008 [89] & QoL study & $\begin{array}{l}\text { Infected and uninfected CHB } \\
\text { health state utilities (CHN, } \\
\text { HKG, CAN, US, GBR, } \\
\text { ESP)-no mention of HBsAg } \\
\text { loss }\end{array}$ & AUS \\
\hline Jones et al. 2009 [45] & 0.79 & & Levy et al. 2008 [89] & QoL study & $\begin{array}{l}\text { Infected and uninfected CHB } \\
\text { health state utilities (CHN, } \\
\text { HKG, CAN, US, GBR, } \\
\text { ESP)-no mention of HBsAg } \\
\text { loss }\end{array}$ & UK \\
\hline Zhang et al. 2015 [34] & 0.71 & $0.64-0.78$ & Levy et al. 2008 [89] & NA & $\begin{array}{l}\text { Infected and uninfected CHB } \\
\text { health state utilities (CHN, } \\
\text { HKG, CAN, US, GBR, } \\
\text { ESP)-no mention of HBsAg } \\
\text { loss }\end{array}$ & $\mathrm{CHN}$ \\
\hline Banerjee et al. 2016 [31] & 0.71 & & Levy et al. 2008 [89] & QoL study & $\begin{array}{l}\text { Infected and uninfected CHB } \\
\text { health state utilities (CHN, } \\
\text { HKG, CAN, US, GBR, } \\
\text { ESP)-no mention of HBsAg } \\
\text { loss }\end{array}$ & $\mathrm{CHN}$ \\
\hline Wei et al. 2013 [27] & 0.71 & & Levy et al. 2008 [89] & QoL study & $\begin{array}{l}\text { Infected and uninfected CHB } \\
\text { health state utilities (CHN, } \\
\text { HKG, CAN, US, GBR, } \\
\text { ESP)-no mention of HBsAg } \\
\text { loss }\end{array}$ & $\mathrm{CHN}$ \\
\hline
\end{tabular}

AUS Australia, CAN Canada, CEA cost-effectiveness analysis, CHB chronic hepatitis B, CHN China, ESP Spain, GBR Great Britain, $H B e A g$ hepatitis B envelope antigen, $H B s A g$ hepatitis B surface antigen, $H K G$ Hong Kong, IRN Iran, ITA Italy, NA not applicable, PMID PubMed identification number, $Q o L$ quality of life, $S E$ standard error, $U K$ United Kingdom, US United States of America 
For ETV, annual HBsAg loss rates between 1.4\% (Ruggeri et al. [28], Zhang et al. [34] and Banerjee et al. [31]) and $2 \%$ (Colombo et al. [41], Ruggeri et al. [28]) are used in $\mathrm{HBeAg-positive} \mathrm{patients,} \mathrm{with} \mathrm{Ruggeri} \mathrm{et} \mathrm{al.} \mathrm{[28]} \mathrm{present-}$ ing annual loss rates for the first 5 years in the study. As was seen for TDF, a $0 \%$ annual loss rate is used in Colombo et al. [41] and a $12 \%$ lifetime loss rate is used by Lo et al. [35] for $\mathrm{HBeAg-negative} \mathrm{patients.} \mathrm{For} \mathrm{studies} \mathrm{that} \mathrm{did} \mathrm{not} \mathrm{differenti-}$ ate $\mathrm{HBsAg}$ loss rates by $\mathrm{HBeAg}$ status, Iannazzo et al. [36] used an annual rate of $0.4 \%$ and $\mathrm{He}$ et al. [38] again used a much higher annual rate of $8.1 \%$.

For LdT, annual HBsAg loss rates are lower than for any other treatments in HBeAg-positive patients. These annual rates range from $0 \%$ (Colombo et al. [41]) to $0.7 \%$ (Zhang et al. [34] and Banerjee et al. [31]). In HBeAg-negative patients, a $0 \%$ annual loss rate is used in Colombo et al. [41] and a $12 \%$ lifetime loss rate is used by Lo et al. [35]. As was seen with LAM, He et al. [38] used a loss rate that was equal to baseline for all patients regardless of HBeAg status.

Banerjee et al. [31] was the only study that mentioned annual HBsAg loss rates for combinations of nucleoside therapies. LDT in combination with ADV was considered to have an annual loss rate of $0.7 \%$, whilst LDT in combination with TDF was considered to have a higher annual loss rate of $4.4 \%$ (both in $\mathrm{HBeAg}$-positive patients).

For interferon (IFN), Jones et al. [45] used an annual HBsAg loss of $1.7 \%$ in HBeAg-positive patients, which was recorded in a study by Zhao et al. [93], yet it was not clear from the report which values were used in the accompanying model. For HBeAg-negative patients, an annual HBsAg loss rate of $18.8 \%$ was recorded in the first year by Wong et al. [52].

For PEG IFN, annual HBsAg loss rates between $0 \%$ (Jones et al. [45]) and 8\% (Colombo et al. [41]) are used in $\mathrm{HBeAg}$-positive patients. As with IFN, the HBsAg loss rate stated in Jones et al. [45] was recorded in a study by Zhao et al. [93], in which no patients experienced HBsAg loss on PEG IFN, though it is not clear from the report which values were used in the accompanying model. The report by Jones et al. [45] should be interpreted with caution due to its seemingly low loss rates compared with similar studies (also, because PEG IFN performed surprisingly worse than IFN alone). In HBeAg-negative patients, Colombo et al. [41] reported an increasing annual loss rate starting with $3 \%$ in year 1 and ending with $8 \%$ in year 3 . This compares with the Lo et al. study [35], which used a lifetime HBsAg loss rate of $35 \%$. For studies that did not differentiate HBsAg loss rates by $\mathrm{HBeAg}$ status, Iannazzo et al. [36] used annual rates starting from $5.3 \%$ in year $1-10.6 \%$ in year 3 .

Jones et al. [45] recorded HBsAg loss rates for PEG IFN in combination with LAM, though it was not clear from the report whether these values were used in the accompanying model. The study reported a loss rate of $10 \%$ as was recorded in a study by Chan et al. [94] (seen in 5 of 50 patients in the study), though it was not clear whether this was a yearly loss rate or overall outcome.

And finally, best supportive care (BSC) was reported by Banerjee et al. [31] to have an annual $\mathrm{HBsAg}$ loss rate of $0.7 \%$ in $\mathrm{HBeAg}$-positive patients. Whilst in HBeAg-negative patients, Lo et al. [35] reported a lifetime loss rate of $10 \%$ and Wong et al. [52] reported an even higher rate of $18.80 \%$. The report by Wong et al. [52], however, stated that the model was purposefully biased against IFN because of significant heterogeneity existing among study results in the meta-analysis that was used.

It is important to note that in the studies that reported increasing annual loss rates (e.g., Iannazzo et al. [36] and Colombo et al. [41]), the last observed response rate was carried forward when further data was not available to the authors. Iannazzo et al. [36] presented HBsAg loss rates after 48 weeks with PEG IFN that seem to suggest that the authors took into account a treatment effect occurring some time after treatment was presumably ended.

\section{Discussion}

HBsAg loss as a health state in economic models of CHB across multiple country perspectives is not well recorded in terms of costs, health state utilities, and treatment-specific transition probabilities. Of the 65 EEs identified in this review, less than half (27/65) incorporated this health state in their models (see Table 1). And of those studies that did record HBsAg loss inputs, the source of the values used (especially for health state costs and utilities as seen in Tables 2 and 4) were largely unclear.

Of the 27 studies that incorporated HBsAg loss, only 15 explicitly mentioned HBsAg loss health state costs (Table 2). The vast majority of sources that were used to collect such costs for the original studies [27, 31, 34, 38, 40, 43, 46-48] do not specifically mention these values in their articles. The only source that does specifically state a cost (in this case for HBsAg SC) is Dakin et al. [86], which states a yearly cost of US\$5.32. The range of costs recorded between the articles is wide (from US\$0.00 [29, 45, 49, 87] to US\$1377.45 [31] per year) and a large disparity seems to exist: five studies [27, 31, 34, 50, 52] state costs between US\$814.83 [40] and US\$1377.45 [31], compared with 11 studies [29, 38, 43, 45-50, 52, 87] that state costs between US\$0.00 [29, 45, 49, 87] and US\$224.62 [50]. From looking at Table 3, which shows the health state costs recorded by the sources referenced, it is likely that the costs for HBsAg loss have been predicted from other $\mathrm{CHB}$ health states. This may explain the disparity between the values used since the studies that contain the higher values may have predicted these from other CHB health states that use higher costs (e.g., the CHB 
health state cited in $\mathrm{Hu}$ et al. [82], which uses an annual cost of US\$1953). It may not be misguided to suggest that most studies are therefore relying on assumptions rather than explicitly sourcing cost inputs, and referencing other studies that have previously relied on assumptions compounds this problem further.

In terms of health state utilities associated with $\mathrm{HBsAg}$ loss, these were explicitly mentioned in only 15 of the 65 EEs identified (see Table 4). Across these studies, the values cited for this health state range from 0.71 (reported in three studies [27, 31, 34]) to 0.99 (reported in four studies [32, 46-48]). All the 0.71 utility values were taken from the same source (Levy et al. [89]), yet there is no mention of utility associated with HBsAg loss in this article. Therefore, the 0.71 value has been assumed to be the same as an alternative health state that is not clearly outlined in the source (likely to be infected patients with $\mathrm{CC}$ ). When exploring the source of the 0.99 utility values, three of the studies (Veenstra et al. [47, 48], and Spackman and Veenstra [46]) assumed that the HBsAg loss health state utility is equal to the $\mathrm{HBeAg}$ seroconversion health state utility using Wong et al. [52] as a reference. And when Wong et al. [52] is explored, the utility values used in this study were derived from an expert panel that assessed their own utilities of being in a particular health state using the standard gamble (SG) and time-tradeoff (TTO) techniques. For the remaining study that reported a value of 0.99 [32], Levy et al. [89] was referenced, yet there was no mention of a utility value of HBsAg loss in the study (this has also been used as a source for five other studies [27, 29, 31, 36, 45]). Bermingham et al. [33] used a utility value for non-cirrhotic CHB (0.87) to represent HBsAg loss, and both Dakin et al. [43] as well as Dakin et al. [40] used UK population norms using EQ-5D (0.86). As was seen with HBsAg loss health state costs, suboptimal reporting as well as a clear lack of transparency regarding the source of HBsAg loss health state utilities is evident. When evidence is not available, sources have relied on using other similar health states as a proxy for HBsAg loss.

Treatment-specific HBsAg loss rates/transition probabilities were reported in only 11 of the 65 EEs identified (see Supplementary Table 5 in the ESM). The number of studies is even lower than the 15 that reported HBsAg loss health state costs (Table 2) and the 15 that reported HBsAg loss health state utilities (Table 4). This is probably explained by the likelihood that most studies do not differentiate between SoC treatments in terms of HBsAg loss. This may be because HBsAg loss (and HBsAg SC) are reported in only a small number of patients, so differentiating these loss rates by specific treatments would result in the outcomes becoming heavily underpowered and unreliable when compared with other studies. An example of this problem is outlined in the report by Jones et al. [45], which reported a $10 \%$ HBsAg loss rate in a study by Chan et al. [94] whereby a small sample size (only 50 patients) received PEG IFN in combination with LAM.

For nucleoside analogues (irrespective of $\mathrm{HBeAg}$ status), annual HBsAg loss rates vary fairly substantially between studies. TDF varies between $0.4 \%$ (Iannazzo et al. [36]) and $11.53 \%$ (He et al. [38]), LAM varies between 0\% (Colombo et al. [41]) and 14\% (Jones et al. [45]), ADV varies between 0\% (Colombo et al. [41]) and 1.3\% (Zhang et al. [34] and Banerjee et al. [31]), ETV varies between 0\% (Colombo et al. [41]) and 8.1\% (He et al. [38]), and LdT varies between 0\% (Colombo et al. [41]) and 0.7\% (Zhang et al. [34] and Banerjee et al. [31]). It is important to note that the higher values for annual HBsAg loss rates (especially by Jones et al. [45] and He et al. [38]) did not seem to be in line with the majority of inputs (which were much lower) reported in the other studies. He et al. [38] cited an RCT (Chang et al. [12]) to obtain its HBsAg loss rate for ETV, yet the rate reported in the study (2\%, i.e., $6 / 354$ at 48 weeks) is much lower than the $8.1 \%$ figure used in the model. Meanwhile, as stated previously, it was not clear which values Jones et al. [45] used in the accompanying EE. In published RCTs, HBsAg loss recorded at 48 weeks for nucleosides rarely reaches $4 \%$ or higher [12-17]; therefore, numerous studies seem to state loss rates that are particularly high in their models.

For IFN, annual HBsAg loss rates (irrespective of $\mathrm{HBeAg}$ status) ranged between 1.7\% (Jones et al. [45]) and 18.8\% (Wong et al. [52]), whilst for PEG IFN, loss rates ranged between 0\% (Jones et al. [45]) and 10.6\% (Iannazzo et al. [36]). A lifetime HBsAg loss rate of $35 \%$ was also recorded for PEG IFN (Lo et al. [35]). However, some of these results need to be interpreted with caution. Jones et al. [45] obtained these values from a study that had a low sample size (Zhao et al. [93]), whilst Wong et al. [52] used assumptions from an expert guidance panel to estimate loss rates. In published RCTs, the loss rate for PEG IFN alone is usually around $4-10 \%$ [18-21], but has also been reported in some studies to be above 10\% [95, 96] (and these also vary by specific genotype [97]). PEG IFN in combination with a nucleoside analogue has been reported in some cases to be even higher: $20 \%$ (2/10 patients) at 60 weeks [22], and $21 \%$ (3/14 patients) at 48 weeks [23], although low sample sizes seem to have an influence. Also, an HBsAg loss rate of $18.8 \%$ (Wong et al. [52]) seems relatively high compared with a rate of $0 \%(0 / 33)$ at 52 weeks [98], and $10 \%(7 / 72)$ at 48 weeks [6] as seen in two published RCTs.

According to the AASLD 2018 [7], APASL 2016 [8], EASL 2017 [9] and NICE 2013 (updated 2017) [10] guidelines, HBsAg loss is a key endpoint of interest that is strongly recommended in the management of HBV. Often, patients that achieve FC are lost to follow up as they will stop attending physician appointments (especially patients that are non-cirrhotic). As such, it is vital in EEs to model all 
important health states (including HBsAg loss in CHB) so that decisions can be made taking into account all available clinical evidence.

From a health economic modelling perspective, the incorporation of HBsAg loss as a health state has the potential to translate into more representative and truer to life health outcomes for the intervention being assessed. This then enables health state-specific utility values and management costs to be incorporated, which can provide credit to interventions that achieve a profound effect on HBsAg loss. The scope of this review was not to provide evidence on how HBsAg loss translates into long-term benefits, but to support future modelling activities so that they do not misrepresent the benefits of curative regimens that are likely to enter the market in the coming years.

Though extensive, this review is not without its limitations. Even though EEs from multiple country perspectives were identified, only studies written in the English language were included for review. This means that the conclusions obtained may be biased towards articles written in English, which may not be seen in studies conducted in other languages.

Studies investigated were not homogenous in terms of baseline patient characteristics. This means that comparisons across studies need to be interpreted with caution due to the fact that these characteristics will undoubtedly influence the outcomes investigated.

The eligibility criteria excluded studies that contained special patient populations. This may have hindered the content of our initial review, and additional searches may be needed to confirm the conclusions in these specific populations. Also, only searches in PubMed and Embase were conducted, which was considered a pragmatic approach with regards to the resources available. Though we do not expect the inclusion of other databases to change our conclusions, this is a limitation of our review.

Overall, there is a clear lack of transparency and reporting surrounding HBsAg loss as a health state in current models of CHB. Future research is required to provide evidence of healthcare resources used for patients that experience HBsAg loss as well as information regarding their HRQoL. With regards to HRQoL, using a disease-specific measure might be better able to capture differences between patients who have HBsAg loss and patients with CHB than conventional questionnaires (e.g. EQ-5D) that may be insensitive to such differences.

\section{Conclusions}

FC is regarded as an optimal endpoint of interest in multiple clinical guidelines (AASLD [7], APASL [8], EASL [9], NICE [10]). However, the benefits of FC in current HE models are not well captured, as they are often not directly related to modelled treatments. This has the potential for novel agents that perform well in increasing the rates of FC to be overlooked and undervalued if their worth is not appropriately communicated. In order to ensure optimal access for patients to new and effective therapies, it is important that the benefits of FC are better assessed and captured within HE models. These include, but are not limited to, the impact on clinical and economic outcomes as well as the effect on HRQoL (especially considering that current treatments for CHB can be taken for long periods of time).

After conducting a systematic literature review of all published HE models of CHB, less than half of these seem to incorporate HBsAg loss as a health state. Most of the models do not consider treatment-specific transition probabilities to the HBsAg loss health state and, when the health state was included, heroic assumptions were made with regards to both HBsAg loss health state costs and HBsAg loss health state utilities. More research is required to provide evidence of healthcare resources used and HRQoL measures for patients that experience $\mathrm{FC}$ so that this can become a vital component incorporated in HE models of CHB.

Author contributions PW and MH had full access to all the data in the study and take responsibility for the integrity of the data and the accuracy of the data analysis. Study concept and design: US, PW, MH. Acquisition of data: PW, MH, TV. Analysis and interpretation of data: PW, MH, US, BH. Drafting of the manuscript: PW, MH, US. Critical revision of the manuscript for important intellectual content: $\mathrm{PW}, \mathrm{MH}$, US, BH, TV. Obtaining funding: BH, MH. Supervision: US.

Data availability statement The data that support the findings of this study are available on request from the corresponding author [PW]. The data are not publicly available due to internal data sharing restrictions within Ingress-health and Janssen Pharmaceutica NV Belgium.

\section{Compliance with Ethical Standards}

Funding This study received funding from Janssen Pharmaceutica NV, Belgium.

Conflict of interest Urbano Sbarigia is an employee of Janssen Pharmaceutica NV Belgium and holds stocks at Johnson \& Johnson. Peter Wigfield, Mahmoud Hashim, and Talitha Vincken are employees at Ingress-health (a research consultancy specialising in health economics and real-world evidence). Bart Heeg is a partner at Ingress-health.

Open Access This article is distributed under the terms of the Creative Commons Attribution-NonCommercial 4.0 International License (http://creativecommons.org/licenses/by-nc/4.0/), which permits any noncommercial use, distribution, and reproduction in any medium, provided you give appropriate credit to the original author(s) and the source, provide a link to the Creative Commons license, and indicate if changes were made. 


\section{References}

1. Hepatitis B (2018) World Health Organisation (WHO). http://www.who.int/news-room/fact-sheets/detail/hepatitis-b. Accessed 19 Oct 2018

2. EASL (2017) Clinical Practice Guidelines on the management of hepatitis B virus infection. http://www.easl.eu/medias/cpg/ management-of-hepatitis-B-virus-infection/English-report.pdf. Accessed 19 Oct 2018

3. EASL (2012) European Association for the Study of the Liver; Clinical Practice Guidelines: Management of chronic hepatitis B virus infection. https://www.journal-of-hepatology.eu/artic le/S0168-8278(12)00167-5/pdf. Accessed 1 Nov 2018

4. WHO (2018) Hepatitis B-Key Facts. World Health Organisation (WHO). http://www.who.int/en/news-room/fact-sheets/ detail/hepatitis-b. Accessed 1 Nov 2018

5. Conditions; Hepatitis B; Treatment (2016) NHS. https://www. nhs.uk/conditions/hepatitis-b/treatment/. Accessed 31 Jan 2019

6. Sokal EM, Conjeevaram HS, Roberts EA, Alvarez F, Bern EM, Goyens P, et al. Interferon alfa therapy for chronic hepatitis B in children: a multinational randomized controlled trial. Gastroenterology. 1998;114(5):988-95.

7. Terrault NA, Lok ASF, Mcmahon BJ, Chang K-M, Hwang JP, Jonas MM, et al. Update on prevention, diagnosis, and treatment of chronic hepatitis B: AASLD 2018 Hepatitis B Guidance. Pract Guid Hepatol. 2018;67(4). https://www.aasld.org/ sites/default/files/HBVGuidance_Terrault_et_al-2018-Hepat ology.pdf. Accessed 28 Jan 2019

8. Sarin S, Kumar M, Lau G, Abbas Z, Chan H, Chen C, et al. Asian-Pacific clinical practice guidelines on the management of hepatitis B: a 2015 update. Hepatol Int. 2016;10:1-98.

9. EASL 2017. Clinical practice guidelines on the management of hepatitis B virus infection. J Hepatol. 2017;67:370-98.

10. Hepatitis B (chronic): diagnosis and management management; Clinical guideline; CG165. 2013. https://www.nice.org.uk/ guidance/cg165/resources/hepatitis-b-chronic-diagnosis-andmanagement-pdf-35109693447109. Accessed 8 Feb 2019

11. Terrault NA, Bzowej NH, Chang K-M, Hwang JP, Jonas MM, Murad MH. AASLD guidelines for the treatment of chronic hepatitis B; objectives and guiding principles. 2015. https:// www.aasld.org/sites/default/files/Terrault_et_al-2016-Hepat ology.pdf. Accessed 1 Nov 2018

12. Chang T-T, Gish RG, de Man R, Gadano A, Sollano J, Chao Y-C, et al. A comparison of entecavir and lamivudine for HBeAg-positive chronic hepatitis B. N Engl J Med. 2006;354(10):1001-10.

13. Lai C-L, Shouval D, Lok AS, Chang T-T, Cheinquer H, Goodman Z, et al. Entecavir versus lamivudine for patients with $\mathrm{HBeAg}$-negative chronic hepatitis B. N Engl J Med. 2006;354(10):1011-20.

14. Lok AS, Trinh H, Carosi G, Akarca US, Gadano A, Habersetzer F, et al. Efficacy of entecavir with or without tenofovir disoproxil fumarate for nucleos(t)ide-naïve patients with chronic hepatitis B. Gastroenterology. 2012;143(3):619.e1-628.ee1.

15. Jonas MM, Chang M-H, Sokal E, Schwarz KB, Kelly D, Kim $\mathrm{KM}$, et al. Randomized, controlled trial of entecavir versus placebo in children with hepatitis B envelope antigen-positive chronic hepatitis B. Hepatology. 2016;63(2):377-87.

16. Sriprayoon T, Mahidol C, Ungtrakul T, Chun-On P, Soonklang $\mathrm{K}$, Pongpun W, et al. Efficacy and safety of entecavir versus tenofovir treatment in chronic hepatitis B patients: a randomized controlled trial. Hepatol Res. 2017;47(3):E161-8. https ://doi.org/10.1111/hepr.12743.

17. An J, Lim Y-S, Kim G-A, Han S-B, Jeong W, Lee D, et al. Telbivudine versus entecavir in patients with undetectable hepatitis B virus DNA: a randomized trial. BMC Gastroenterol. 2017;17(1):15. https://doi.org/10.1186/s12876-017-0572-2.

18. Xie Q, Zhou H, Bai X, Wu S, Chen J-J, Sheng J, et al. A randomized, open-label clinical study of combined pegylated interferon Alfa-2a (40KD) and entecavir treatment for hepatitis B "e" antigen - positive chronic hepatitis B. Clin Infect Dis. 2014;59(12):1714-23. https://doi.org/10.1093/cid/ciu702.

19. Sun J, Ma H, Xie Q, Xie Y, Sun Y, Wang H, et al. Responseguided peginterferon therapy in patients with $\mathrm{HBeAg}$-positive chronic hepatitis B: a randomized controlled study. J Hepatol. 2016;65(4):674-82.

20. Ning Q, Han M, Sun Y, Jiang J, Tan D, Hou J, et al. Switching from entecavir to PegIFN alfa-2a in patients with HBeAg-positive chronic hepatitis B: a randomised open-label trial (OSST trial). J Hepatol. 2014;61(4):777-84.

21. Tangkijvanich $P$, Chittmittraprap S, Poovorawan K, Limothai U, Khlaiphuengsin A, Chuaypen N, et al. A randomized clinical trial of peginterferon alpha-2b with or without entecavir in patients with $\mathrm{HBeAg}$-negative chronic hepatitis $\mathrm{B}$ : role of host and viral factors associated with treatment response. J Viral Hepat. 2016;23(6):427-38. https://doi.org/10.1111/jvh.12467.

22. Cannizzo ES, Tincati C, Binda F, Ronzi P, Cazzaniga FA, Antinori $\mathrm{S}$, et al. Unconventional $\mathrm{T}$ cells in chronic hepatitis B patients on long-term suppressive therapy with tenofovir followed by a Peg-IFN add-on strategy: a randomized study. J Viral Hepat. 2018;25(4):381-90. https://doi.org/10.1111/jvh.12820.

23. Bourlière M, Rabiega P, Ganne-Carrie N, Serfaty L, Marcellin $\mathrm{P}$, Barthe Y, et al. Effect on HBs antigen clearance of addition of pegylated interferon alfa-2a to nucleos(t)ide analogue therapy versus nucleos(t)ide analogue therapy alone in patients with $\mathrm{HBe}$ antigen-negative chronic hepatitis $\mathrm{B}$ and sustained undetectable plasma hepatitis. Lancet Gastroenterol Hepatol. 2017;2(3):177-88.

24. Drummond MF, Sculpher MJ, Claxton K, Stoddart GL, Torrance GW. Methods for the economic evaluation of health care programmes. 4th ed. Oxford: Oxford University Press; 2015.

25. Moher D, Liberati A, Tetzlaff J, Altman DG, PRISMA Group. Preferred reporting items for systematic reviews and meta-analyses: the PRISMA statement. PLoS Med. 2009;6(7):e1000097.

26. Kockaya G, Kose A, Yenilmez FB, Ozdemir O, Kucuksayrac E. Cost-effectiveness analysis of oral anti-viral drugs used for treatment of chronic hepatitis B in Turkey. Cost Eff Resour Alloc. 2015;13(1):1-10.

27. Wei L, Hu S, Hou J, Liu G, Ren H, Duan Z, et al. A novel estimation of the impact of treatment with entecavir on long-term mortality, morbidity, and health care costs of chronic hepatitis b in China. Value Heal Reg Issues. 2013;2(1):48-56. https://doi. org/10.1016/j.vhri.2013.02.002.

28. Ruggeri M, Basile M, Coretti S, Drago C, Cicchetti A. Economic analysis and budget impact of tenofovir and entecavir in the firstline treatment of hepatitis B virus in Italy. Appl Health Econ Health Policy. 2017;15(4):479-90. https://doi.org/10.1007/s4025 8-017-0311-4.

29. Chinnaratha MA, Kaambwa B, Woodman RJ, Fraser RJ, Wigg AJ. Assessing the clinical and economic impact of increasing treatment uptake in chronic hepatitis B infection using a Markov model. J Gastroenterol Hepatol. 2017;32(7):1370-7. https://doi. org/10.1111/jgh.13679.

30. Keshavarz K, Kebriaeezadeh A, Alavian SM, Akbari Sari A, Rezaei Hemami M, Lotfi F, et al. A cost-utility and costeffectiveness analysis of different oral antiviral medications in patients with $\mathrm{HBeAg-negative} \mathrm{chronic} \mathrm{hepatitis} \mathrm{B} \mathrm{in} \mathrm{Iran:}$ an economic microsimulation decision model. Hepat Mon. 2016;16(9):e37435.

31. Banerjee S, Gunda P, Drake RF, Hamed K. Telbivudine for the treatment of chronic hepatitis B in $\mathrm{HBeAg}$-positive patients in 
China: a health economic analysis. Springerplus. 2016;5(1):1719. https://doi.org/10.1186/s40064-016-3404-x.

32. Toy M, Hutton DW, So SK. Cost-effectiveness and cost thresholds of generic and brand drugs in a national chronic hepatitis B treatment program in China. Kim DY, editor. PLoS One. 2015;10(11):e0139876. https://doi.org/10.1371/journ al.pone.0139876.

33. Bermingham SL, Hughes R, Fenu E, Sawyer LM, Boxall E, Kennedy TP, et al. Cost-effectiveness analysis of alternative antiviral strategies for the treatment of $\mathrm{HBeAg}$-positive and $\mathrm{HBeAg}$-negative chronic hepatitis B in the United Kingdom. Value Health. 2015;18(6):800-9.

34. Zhang C, Ke W, Gao Y, Zhou S, Liu L, Ye X, et al. Cost-effectiveness analysis of antiviral therapies for hepatitis B e antigen-positive chronic hepatitis B patients in China. Clin Drug Investig. 2015;35(3):197-209. https://doi.org/10.1007/s4026 1-015-0273-y.

35. Lo AO-S, Wong VW-S, Wong GL-H, Chan HL-Y, Dan Y-Y. Cost effectiveness of response-guided therapy with peginterferon in the treatment of chronic hepatitis B. Clin Gastroenterol Hepatol. 2015;13(2):377.e5-385.e5.

36. Iannazzo S, Coco B, Brunetto MR, Rossetti F, Caputo A, Latour $\mathrm{A}$, et al. Individualized treatment of $\mathrm{HBeAg-negative} \mathrm{chronic}$ hepatitis $B$ using pegylated interferon- $\alpha 2 \mathrm{a}$ as first-line and week12 HBV DNA/HBsAg stopping rule: a cost-effectiveness analysis. Antivir Ther. 2013;18(4):623-33.

37. Hulstaert F, Schwierz C, Nevens F, Thiry N, Gamil M, Colle I, et al. Should chronic hepatitis B be treated as early as possible? Int J Technol Assess Health Care. 2013;29(1):35-41.

38. He J, Bowen JM, Xie F, Goeree R. Cost-effectiveness analysis of antiviral treatments for $\mathrm{HBeAg}$-positive chronic hepatitis B in Canada. Value Health. 2012;15(6):894-906.

39. Toy M, Onder FO, Idilman R, Kabacam G, Richardus JH, Bozdayi M, et al. The cost-effectiveness of treating chronic hepatitis B patients in a median endemic and middle income country. Eur J Health Econ. 2012;13(5):663-76.

40. Dakin H, Sherman M, Fung S, Fidler C, Bentley A. Cost effectiveness of tenofovir disoproxil fumarate for the treatment of chronic hepatitis B from a Canadian public payer perspective. Pharmacoeconomics. 2011;29(12):1075-91. https://doi. org/10.2165/11589260-000000000-00000.

41. Colombo GL, Gaeta GB, Viganò M, Di Matteo S. A cost-effectiveness analysis of different therapies in patients with chronic hepatitis B in Italy. Clinicoecon Outcomes Res. 2011;3:37-46.

42. Wiens A, Venson R, Correr CJ, Pontarolo R. Cost-effectiveness of telbivudine versus lamivudine for chronic hepatitis B. Braz J Infect Dis. 2011;15(3):225-30. https://doi.org/10.1016/S1413 $-8670(11) 70180-5$

43. Dakin H, Bentley A, Dusheiko G. Cost-utility analysis of tenofovir disoproxil fumarate in the treatment of chronic hepatitis B. Value Health. 2010;13(8):922-33.

44. Shepherd J, Gospodarevskaya E, Frampton G, Cooper K. Entecavir for the treatment of chronic hepatitis B infection. Health Technol Assess. 2009;13(Suppl 3):31-6.

45. Jones J, Shepherd J, Baxter L, Gospodarevskaya E, Hartwell $\mathrm{D}$, Harris $\mathrm{P}$, et al. Adefovir dipivoxil and pegylated interferon alpha for the treatment of chronic hepatitis B: an updated systematic review and economic evaluation. Health Technol Assess. 2009;13(35):1-172.

46. Spackman DE, Veenstra DL. A cost-effectiveness analysis of currently approved treatments for $\mathrm{HBeAg}$-positive chronic hepatitis B. Pharmacoeconomics. 2008;26(11):937-49. https://doi. org/10.2165/00019053-200826110-00006.

47. Veenstra DL, Spackman DE, Di Bisceglie A, Bisceglie A, Kowdley KV, Gish RG. Evaluating anti-viral drug selection and treatment duration in $\mathrm{HBeAg-negative} \mathrm{chronic}$ hepatitis B: a cost-effectiveness analysis. Aliment Pharmacol Ther. 2008;27(12):1240-52. https://doi.org/10.111 1/j.1365-2036.2008.03691.x.

48. Veenstra DL, Sullivan SD, Clarke L, Iloeje UH, Tafesse E, Di Bisceglie A, et al. Cost effectiveness of entecavir versus lamivudine with adefovir salvage in $\mathrm{HBeAg}$-positive chronic hepatitis B. Pharmacoeconomics. 2007;25(11):963-77. https://doi. org/10.2165/00019053-200725110-00006.

49. Takeda A, Jones J, Shepherd J, Davidson P, Price A. A systematic review and economic evaluation of adefovir dipivoxil and pegylated interferon-alpha-2a for the treatment of chronic hepatitis B. J Viral Hepat. 2007;14(2):75-88. https://doi.org/10.111 1/j.1365-2893.2006.00808.x.

50. Pwu R-F, Chan KA. Cost-effectiveness analysis of interferonalpha therapy in the treatment of chronic hepatitis B in Taiwan. J Formos Med Assoc. 2002;101(9):632-41.

51. Louis-Jacques $\mathrm{O}$, Olson AD. Cost-benefit analysis of interferon therapy in children with chronic active hepatitis B. J Pediatr Gastroenterol Nutr. 1997;24(1):25-32.

52. Wong JB, Koff RS, Tinè F, Pauker SG. Cost-effectiveness of interferon-alpha $2 \mathrm{~b}$ treatment for hepatitis $\mathrm{B}$ e antigen-positive chronic hepatitis B. Ann Intern Med. 1995;122(9):664-75.

53. Orlewska E. The cost-effectiveness of alternative therapeutic strategies for the management of chronic hepatitis B in Poland. Value Health. 2002;5(5):405-21. https://doi.org/10.10 46/J.1524-4733.2002.55147.x.

54. Dusheiko GM, Roberts JA. Treatment of chronic type B and C hepatitis with interferon alfa: an economic appraisal. Hepatology. 1995;22(6):1863-73.

55. Crowley SJ, Tognarini D, Desmond PV, Lees M. Cost-effectiveness analysis of lamivudine for the treatment of chronic hepatitis B. Pharmacoeconomics. 2000;17(5):409-27. https://doi. org/10.2165/00019053-200017050-00001.

56. Wang G, Liu Y, Qiu P, Zhou SF, Xu L, Wen P, et al. Cost-effectiveness analysis of lamivudine, telbivudine, and entecavir in treatment of chronic hepatitis B with adefovir dipivoxil resistance. Drug Des Dev Ther. 2015;9:2839-46.

57. de Oliveira GLA, Almeida AM, da Silva AL, Brandão CMR, Andrade EIG, Cherchiglia ML, et al. Incorporated antivirals for chronic hepatitis b in Brazil: a cost-effectiveness analysis. Rev Saude Publica. 2013;47(4):1-11.

58. Tsai N, Jeffers L, Cragin L, Sorensen S, Su W, Rosenblatt L, et al. Cost-effectiveness of entecavir versus adefovir for the treatment of chronic hepatitis $b$ in patients with decompensated cirrhosis from a third-party US payer perspective. Clin Outcomes Res. 2012;4(1):227-35.

59. Almeida AMI, Da Silva AL, Cherchiglia ML, Andrade EIG, De Oliveira GLA, De Assis Acurcio F. Chronic hepatitis B treatment: The cost-effectiveness of interferon compared to lamivudine. Value Health. 2011;14(5 suppl):S24-8. https://doi. org/10.1016/j.jval.2011.05.011.

60. Lui YYN, Tsoi KKF, Wong VWS, Kao JH, Hou JL, Teo EK, et al. Cost-effectiveness analysis of roadmap models in chronic hepatitis B using tenofovir as the rescue therapy. Antivir Ther. 2010;15(2):145-55.

61. Buti M, Casado MA, Calleja JL, Salmerón J, Aguilar J, Rueda M, et al. Cost-effectiveness analysis of lamivudine and adefovir dipivoxil in the treatment of patients with $\mathrm{HBeAg}$ negative chronic hepatitis B. Aliment Pharmacol Ther. 2006;23(3):409-19.

62. Park JY, Heo J, Lee TJ, Yim HJ, Yeon JE, Lim Y-S, et al. A novel estimation of the relative economic value in terms of different chronic hepatitis B treatment options. Lubell Y, editor. PLoS One. 2013;8(3):e57900.

63. Crowley S, Tognarini D, Desmond P, Lees M, Saal G. Introduction of lamivudine for the treatment of chronic hepatitis 
B: expected clinical and economic outcomes based on 4-year clinical trial data. J Gastroenterol Hepatol. 2002;17(2):153-64.

64. Brooks EA, Lacey LF, Payne SL, Miller DW. Economic evaluation of lamivudine compared with interferon-alpha in the treatment of chronic hepatitis B in the United States. Am J Manag Care. 2001;7(7):677-82.

65. Orlewska E, Zammit D, Yuan Y, Kutikova L, Berak H, Halota $\mathrm{W}$, et al. The cost-effectiveness analysis of entecavir in the treatment of chronic hepatitis B (CHB) patients in Poland. Exp Clin Hepatol. 2008;4(3-4):20-8.

66. Lee KKC, Wu DBC, Chow PY, Lee VWY, Li H. Economic analysis between entecavir and lamivudine for the treatment of chronic hepatitis B in Hong Kong. J Gastroenterol Hepatol. 2012;27(7):1167-74.

67. Arnold E, Yuan Y, Iloeje U, Cook G. Cost-effectiveness analysis of entecavir versus lamivudine in patients with chronic hepatitis B. Appl Health Econ Health Policy. 2008;38(4):260-73.

68. Costa AMN, Italien GL, Nita ME, Araujo ESA. Cost-effectiveness of entecavir versus lamivudine for the suppression of viral replication in chronic hepatitis B patients in Brazil. Braz J Infect Dis. 2008;12(5):368-73.

69. Yuan Y, Iloeje U, Li H, Hay J, Yao GB. Economic implications of entecavir treatment in suppressing viral replication in chronic hepatitis B (CHB) patients in China from a perspective of the Chinese Social Security program. Value Health. 2008;11(Suppl. 1):S11-22. https://doi.org/10.111 1/j.1524-4733.2008.00362.x.

70. Yuan Y, Iloeje UH, Hay J, Saab S. Evaluation of the costeffectiveness of entecavir versus lamivudine in hepatitis BeAgpositive chronic hepatitis B patients. J Manag Care Pharm. 2008;14(1):21-33. https://doi.org/10.18553/jmcp.2008.14.1.21.

71. Wu B, Li T, Chen H, Shen J. Cost-effectiveness of nucleoside analog therapy for hepatitis B in china: a markov analysis. Value Health. 2010;13(5):592-600.

72. Zhang H, Huo M, Chao J, Liu P. Application of Bayesian approach to cost-effectiveness analysis of antiviral treatments in chronic hepatitis B. PLoS One. 2016;11(8):1-9.

73. Ke W, Zhang C, Liu L, Gao Y, Yao Z, Ye X, et al. Cost-effectiveness analysis of tenofovir disoproxil fumarate for treatment of chronic hepatitis B in China. Hepatol Int. 2016;10(6):924-36.

74. Lai K, Zhang C, Ke W, Gao Y, Zhou S, Liu L, et al. Cost-effectiveness comparison between the response-guided therapies and monotherapies of nucleos(t)ide analogues for chronic hepatitis B patients in China. Clin Drug Investig. 2017;37(3):233-47.

75. Goyal A, Murray JM. Cost-effectiveness of peg-interferon, interferon and oral nucleoside analogues in the treatment of chronic hepatitis B and D infections in China. Clin Drug Investig. 2016;36(8):637-48.

76. Zhang C, Ke W, Liu L, Gao Y, Yao Z, Ye X, et al. Cost-effectiveness comparison of lamivudine plus adefovir combination treatment and nucleos $(\mathrm{t})$ ide analog monotherapies in Chinese chronic hepatitis B patients. Drug Des Dev Ther. 2016;10:897-910.

77. Wu B, Shen J, Cheng H. Cost-effectiveness analysis of different rescue therapies in patients with lamivudine-resistant chronic hepatitis B in China. BMC Health Serv Res. 2012;12(1):1-13.

78. Tsai N, Jeffers L, Cragin L, Sorensen S, Su W, Rosenblatt L, et al. Cost-effectiveness of entecavir versus adefovir for the treatment of chronic hepatitis B in patients with decompensated cirrhosis from a third-party US payer perspective. Clinicoecon Outcomes Res. 2012;4:227-35.

79. Enriquez AD, Campbell MS, Reddy KR. Cost-effectiveness of suppressing hepatitis B virus DNA in immune tolerant patients to prevent hepatocellular carcinoma and cirrhosis. Aliment Pharmacol Ther. 2007;26(3):383-91.

80. Kanwal F, Gralnek IM, Martin P, Dulai GS, Farid M, Spiegel BMR. Treatment alternatives for chronic hepatitis B virus infection: a cost-effectiveness analysis. Ann Intern Med. 2005;142(10):821-31.

81. Veenstra DL, Sullivan SD, Dusheiko GM, Jacobs M, Aledort JE, Lewis G, et al. Cost-effectiveness of peginterferon $\alpha-2 \mathrm{a}$ compared with lamivudine treatment in patients with $\mathrm{HBe}$-antigenpositive chronic hepatitis B in the United Kingdom. Eur J Gastroenterol Hepatol. 2007;19(8):631-8.

82. Hu M, Chen W. Assessment of total economic burden of chronic hepatitis B (CHB)-related diseases in Beijing and Guangzhou, China. Value Health. 2009;12(Suppl 3):S89-92.

83. KASL. KASL Clinical Practice Guidelines: management of chronic hepatitis B. Clin Mol Hepatol. 2012;18(2):109-62.

84. Pharmaceutical Benefit Scheme for National Health Insurance. Taipei Bur Natl Heal Insur. 1999;(ROC).

85. Gagnon YM, Levy AR, Iloeje UH, Briggs AH. Treatment costs in Canada of health conditions resulting from chronic hepatitis B infection. J Clin Gastroenterol. 2018;38(10 Suppl 3):S179-86.

86. Dakin H, Fidler C, Harper C. Mixed treatment comparison metaanalysis evaluating the relative efficacy of nucleos(t)ides for treatment of nucleos(t)ide-naive patients with chronic hepatitis B. Value Health. 2010;13(8):934-45.

87. Shepherd J, Jones J, Takeda A, Davidson P, Price A. Adefovir dipivoxil and pegylated interferon alfa-2a for the treatment of chronic hepatitis B: a systematic review and economic evaluation. Health Technol Assess. 2006;10(28):1-183 (iii-iv, xi-xiv).

88. Dakin H, Bentley A, Dusheiko G. Cost-utility analysis of tenofovir disoproxil fumarate in the treatment of chronic hepatitis B. Value Health. 2010;13(8):922-33. https://doi.org/10.111 1/j.1524-4733.2010.00782.x.

89. Levy AR, Kowdley KV, Iloeje U, Tafesse E, Mukherjee J, Gish $\mathrm{R}$, et al. The impact of chronic hepatitis B on quality of life: a multinational study of utilities from infected and uninfected persons. Value Health. 2008;11(3):527-38.

90. Goudarzi R. Estimating quality weights for EQ-5D health states with the time trade-off (TTO) method in Iran (Dissertation). Iran: Tehran University of Medical Sciences. 2014.

91. Woo G, Tomlinson G, Yim C, Lilly L, Therapondos G, Wong DKH, et al. Health state utilities and quality of life in patients with hepatitis B. Can J Gastroenterol. 2012;26(7):445-51.

92. Kind P, Hardman G Macran S. UK population norms for EQ-5D. York: Cent Heal Econ. 1999

93. Zhao H, Kurbanov F, Wan M-B, Yin Y-K, Niu J-Q, Hou J-L, et al. Genotype B and younger patient age associated with better response to low-dose therapy: a trial with pegylated/nonpegylated interferon-2b for hepatitis $B$ e antigen-positive patients with chronic hepatitis B in China. Clin Infect Dis. 2007;44(4):541-8.

94. Chan HL-Y, Leung NW-Y, Hui A-Y, Wong VW-S, Liew C-T, Chim AM-L, et al. A randomized, controlled trial of combination therapy for chronic hepatitis B: comparing pegylated interferonalpha2 $\mathrm{b}$ and lamivudine with lamivudine alone. Ann Intern Med. 2005;142(4):240-50.

95. He LT, Ye XG, Zhou XY. Effect of switching from treatment with nucleos(t)ide analogs to pegylated interferon $\alpha-2 \mathrm{a}$ on virological and serological responses in chronic hepatitis B patients. World J Gastroenterol. 2016;22(46):10210-8.

96. Huang J, Zhang K, Chen W, Liao J, Luo X, Chen R. Switching to PegIFN $\alpha-2 b$ leads to HBsAg loss in patients with low HBsAg levels and HBV DNA suppressed by NAs. Sci Rep. 2017;7(1):13383.

97. Marcellin P, Ahn SH, Ma X, Caruntu FA, Tak WY, Elkashab M, et al. Combination of tenofovir disoproxil fumarate and peginterferon $\alpha$-2a increases loss of hepatitis B surface antigen in patients with chronic hepatitis B. Gastroenterology. 2016;150(1):134. e10-144.e10.

98. Ayaz C, Celen MK, Colak H, Hosoglu S, Geyik MF. Comparison of lamivudine and alpha-interferon combination with 
alpha-interferon alone in the treatment of $\mathrm{HBeAg}$-positive chronic hepatitis B. Indian J Gastroenterol. 2018;25(2):71-3.

99. Dan YY, Wong JB, Hamid SS, Han KH, Jia JD, Liu CJ, et al. Consensus cost-effectiveness model for treatment of chronic hepatitis B in Asia Pacific countries. Hepatol Int. 2014;8(3):382-94.

100. Oyagüez I, Buti M, Brosa M, Rueda M, Casado MA. Costeffectiveness and clinical impact of antiviral strategies of HBeAg-positive and -negative chronic hepatitis B. Ann Hepatol. 2019;16(3):358-65.

101. Tantai N, Chaikledkaew U, Tanwandee T, Werayingyong P, Teerawattananon Y. A cost-utility analysis of drug treatments in patients with $\mathrm{HBeAg}$-positive chronic hepatitis B in Thailand. BMC Health Serv Res. 2014;14(1):1-13.

102. Wiens A, Lenzi L, Venson R, Pedroso MLA, Correr CJ, Pontarolo R. Economic evaluation of treatments for chronic hepatitis B. Braz J Infect Dis. 2013;17(4):418-26. https://doi. org/10.1016/j.bjid.2012.12.005.

103. Vanagas G, Padaiga Z, Mickevičienè A. Cost-effectiveness and cost-utility of the treatment of chronic hepatitis B with peginterferon alfa-2a, interferon alfa, and lamivudine in Lithuania. Medicina (Kaunas). 2010;46(12):835-42.

104. Buti M, Brosa M, Casado MA, Rueda M, Esteban R. Modeling the cost-effectiveness of different oral antiviral therapies in patients with chronic hepatitis B. J Hepatol. 2009;51(4):640-6. https://doi.org/10.1016/j.jhep.2009.04.013.

105. Lacey L, Chien RN, Chuang WL, Pwu RF. Economic evaluation of chronic hepatitis B treatments in Taiwan. J Gastroenterol Hepatol. 2008;23(4):571-9.

106. Veenstra DL, Sullivan SD, Lai MY, Lee CM, Tsai CM, Patel $\mathrm{KK}$. HBeAg-negative chronic hepatitis B: cost-effectiveness of peginterferon alfa-2a compared to lamivudine in Taiwan. Value Health. 2008;11(2):131-8. https://doi.org/10.111 1/j.1524-4733.2007.00221.x.

107. Lacey LF, Gane E. The cost-effectiveness of long-term antiviral therapy in the management of $\mathrm{HBeAg}$-positive and $\mathrm{HBeAg}$ negative chronic hepatitis B in Singapore. J Viral Hepat. 2007;14(11):751-66.

108. Sullivan SD, Veenstra DL, Chen PJ, Chang TT, Chuang WL, Tsai $\mathrm{C}$, et al. Cost-effectiveness of peginterferon alfa-2a compared to lamivudine treatment in patients with hepatitis B e antigen positive chronic hepatitis B in Taiwan. J Gastroenterol Hepatol. 2007;22(9):1494-9.

109. Aggarwal R, Ghoshal UC, Naik SR. Treatment of chronic hepatitis B with interferon-alpha: cost-effectiveness in developing countries. Natl Med J India. 2019;15(6):320-7. 